\title{
BITTENCOURT, João Batista de Menezes. Juventudes contemporâneas: desafios e expectativas em transformação. Rio de Janeiro: Telha, 2020.
}

\section{Nicole Kunze Rigon ${ }^{1}$}

A coletânea que foi lançada na 32ª Reunião Brasileira de Antropologia em 2020 reúne textos de dez pesquisadoras e pesquisadores da Rede de Estudos e Pesquisas sobre Experiências e Ações Juvenis (REAJ) e nos oferece novos olhares antropológicos sobre as juventudes contemporâneas. Organizada por João Bittencourt, esta coleção de textos nos dá a conhecer experiências e realidades de jovens de diversas cidades brasileiras, sobretudo nordestinas, dos estados do Ceará, Paraíba, Bahia e Alagoas, e conta também com dois estudos contextualizados em São Paulo.

A partir da leitura dos textos a categoria juventudes adquire novos contornos e suas caracterizações vão além das restritivas perspectivas identitárias. As autoras e autores se preocupam em sinalizar as formas como os diversos aspectos da condição social de jovens afetam seus modos de viver e pensar. Somado a isso, os textos propõem novas abordagens etnográficas e novas estratégias metodológicas para os estudos sobre juventudes, diversificando cada vez mais os debates na área.

Buscando costurar os textos a partir das temáticas pulsantes nesta coletânea deslocamentos geográficos e afetivos, expressividades artísticas e geração de renda -, apresento a seguir algumas considerações sobre os artigos, sugerindo um percurso de leitura alternativo à forma como foram ordenados no livro². Inicialmente serão apresentados os artigos que abordam deslocamentos espaciais e subjetivos, depois aqueles que tratam das expressões artísticas juvenis e, por fim, os que falam sobre os desafios e contradições do mundo do trabalho e da geração de renda nas trajetórias juvenis.

A partir de suas experiências de pesquisa entre rolês pela cidade e fluxos de funk em São Paulo, Alexandre Pereira apresenta uma contribuição metodológica para pensar a circulação de jovens por diferentes espaços das cidades. Inspirado por George Marcus (1995), ele empreende uma pesquisa multissituada cujos trajetos foram conduzidos pelo seu próprio

\footnotetext{
${ }^{1}$ Mestra em Antropologia Social pela Universidade Federal do Rio Grande do Sul e pesquisadora do Núcleo de Antropologia Visual (Navisual/UFRGS).

${ }^{2} \mathrm{O}$ organizador da coletânea comunica na apresentação que os artigos foram colocados na ordem em que foram apresentados no II Seminário Juventudes Contemporâneas, ocorrido em 2017 na UFAL, que inspirou a elaboração do livro.
} 
movimento de seguir fenômenos, coisas, histórias, biografias ou conflitos referentes às juventudes, construíndo pontes entre estes através da observação de suas similaridades.

Percorrendo uma rua com bares perto da universidade, uma praça em um bairro periférico e uma praça na região industrial do ABCD paulista ${ }^{3}$, o pesquisador dialoga com grupos de jovens universitários, skatistas, adeptos da cultura hip-hop, participantes de batalhas de rimas, fãs de reggae e grupos LGBT's, buscando saber quais os fatores que condicionam as experiências e a circulação desses jovens pela cidade.

Estes sujeitos ocupam e se deslocam pelos espaços da cidade, muitas vezes em contraposição às estratégias reguladoras, fazendo deles espaços praticados (CERTEAU, 2009). Entre as similaridades observadas por Pereira nesses espaços é que há sempre uma combinação de três forças que regem as sociabilidades juvenis locais: "o Estado, o mercado e a criatividade das pessoas comuns em seus arranjos cotidianos para tentar levar uma vida mais plena" (p. 28). É no diálogo, e muitas vezes no conflito, com essas forças, que jovens constroem suas dinâmicas de circulação e encontros nos espaços da cidade.

Além dos rolês pelos espaços da cidade, a análise de movimentos de outra ordem, a afetiva, produz rendimentos interessantes рага debater dinâmicas de subjetividade de jovens nas metrópoles contemporâneas. É o que nos mostra João Bittencourt em seu artigo que versa sobre a utilização do método da etnocartografia em sua pesquisa com os straightedges em São Paulo. O autor parte da constatação de que as pesquisas sobre juventudes enfatizam frequentemente as identidades juvenis mas os processos que as tornam possíveis nem sempre aparecem nas análises. Assim, para descrever esses processos, o autor emprega um método que resulta do encontro entre a etnografia e a cartografia, em que a etnografia "permite uma maior aproximação do grupo estudado e uma melhor compreensão de suas práticas" (p. 117) e a cartografia cumpre a função de "ajudar o pesquisador a acompanhar os movimentos do desejo, a apontar as linhas de força, as intensidades e os afetos que compõem as formações subjetivas" (BITTENCOURT, 2020, p. 117).

Como caso prático de utilização da etnocartografia o autor apresenta sua pesquisa, na qual buscava compreender como se construiam diferentes formas de adesão ao movimento straightedge - "um desdobramento da cultura punk" (p. 117) -, algumas mais fanáticas e outras mais contidas. Ele argumenta que em um mesmo movimento existem diversos "graus de

\footnotetext{
${ }^{3}$ Região metropolitana de São Paulo.

${ }^{4}$ De acordo com o Bittencourt (2020), o termo cartografia começa a ser utilizado por Gilles Deleuze em 1986, sendo esta compreendida como "uma prática que se propõe efetuar uma leitura dos processos de subjetivação responsaveis pela (des)organização da vida social e política das populações" (p. 123).
} 
afetação", fazendo com que as pessoas tenham diferentes níveis de identificação com o movimento, algumas delas apaixonadas, outras que seguem suas diretrizes mas não aderem à nomenclatura, umas mais conservadoras, outras mais libertárias, entre outras.

Os processos de engajamento e suas diferentes intensidades estão correlacionados às subjetividades dos sujeitos pois, como argumenta o autor, os afetos são determinantes das formas de pertencimento ao estilo de vida straightedge. A etnocartografia se propõe a explorar essa questão, mapeando movimentos a nível subjetivo e construindo uma pesquisa que se desenvolve através do ato de seguir os afetos para compreender "enunciados e práticas expressados pelos agentes" (p. 123). Assim, conclui Bittencourt, "mais do que um estudo sobre grupos, a etnocartografia é um estudo sobre os afetos, ou melhor, sobre os movimentos que estes operam nos corpos, permitindo as emergências de territórios subjetivos menos ou mais porosos" (p. 134).

Na vereda dos estudos sobre subjetividades e micropolíticas dos afetos, Glória Diógenes explora em seu artigo as lacunas existentes entre a forma como políticas para juventudes são construídas e a realidade cotidiana de jovens brasileiros. As lacunas, "entre lugares" ou "lugares que não existem", nos termos da autora, compreendem abstrações onde se originam os elementos criativos das culturas juvenis. Segundo a autora, percorrer analiticamente estes espaços em que se proliferam as "mobilizações subjetivas" de jovens é um exercício que coloca novos desafios às pesquisas contemporâneas sobre juventudes e cidades.

Nos domínios dessas lacunas "não se pode discernir o que é público ou privado, legal ou ilegal, permitido e proibido" (p. 43) e quaisquer possibilidades de rotulações se mostram escorregadias. É nesse "jogo de ambiguidades" que se desvela a relação entre jovens e cidade, suas formas de apropriação, intervenção, aceitação ou recusa das espacialidades e condições urbanas. É nessas "interzonas" que se inserem as práticas juvenis na arte e na cidade. O texto de Diógenes nos incita a imaginar o que existe ali que se manifesta nas práticas artísticas juvenis. Assim, a autora convida as leitoras a desestabilizarem seus conceitos, desterritorializarem suas pesquisas e, ainda, percorrerem "caminhos que ainda não existem, dimensões de um outro regime, afora o representativo, que largueiam novelos de percepção acerca do sensível e das sensibilidades" (p. 45).

Para ilustrar seus argumentos, Diógenes apresenta um caso específico, o de um painel que foi pintado no Farol do Macuripe em Fortaleza. Até então, tal farol estava esquecido e deteriorado nas paisagens da cidade e a pintura em seu corpo voltou a chamar a atenção da população local, mas não por apreciação à arte. O farol ganhou visibilidade com a polêmica que definia a pintura do painel como um ato de vandalismo. Pode-se dizer que, mesmo que 
circundado por controvérsias a seu respeito, o graffiti, em certa medida, atualizou a biografia daquele lugar (p. 51) e conflagrou um debate em torno do valor do farol para a cidade e seus moradores. Diógenes cita alguns debates recentes que, a partir de casos como este, têm abordado o graffiti também como uma tática de patrimonialização da cidade. A autora em seu artigo nos mostra como, através destes atos, se renovam as micropolíticas juvenis capazes de transformar olhares e cidades, tensionando moralidades e visões de mundo que regem estes espaços compartilhados.

Operando dentro de um "regime estético das juventudes" (DIÓGENES, 2020, p. 51) o caso do Farol de Macuripe é mais uma demonstração das expressividades visuais das juventudes. Entretanto, além da comunicação visual das artes urbanas, a palavra falada, rimada ou cantada também é uma importante manifestação artística. A temática dos ritmos, voz e música é percorrida nos artigos de Tella, Tavares e Marcon, nos quais os autores nos apresentam outras faces das manifestações artísticas juvenis.

Neste campo, o hip-hop tem grande expressividade, sobretudo como manifestação cultural da juventude negra e moradora de periferias brasileiras. Tais jovens são frequentemente associados a comportamentos desviantes ou violentos nas concepções da agenda de segurança pública, da mídia e da opinião popular. Esses olhares condenatórios compõem ideais racistas sobre relações étnico-raciais e influenciam a forma como são construídas as políticas públicas no país. Diante destes fatos, Marco Tella nos mostra em seu artigo como o rap e o break se apresentam como expressões culturais que vão na contramão dessas concepções discriminatórias.

A análise das práticas performáticas de jovens ligados à cultura hip-hop nas cidades de João Pessoa e Rio Tinto foi a estratégia metodológica adotada pelo autor para estudar a condição juvenil nessas cidades. Tais práticas, segundo ele, são "as maneiras de se expressar no e pelo corpo, nas roupas, nas práticas artísticas, nos gostos musicais, nos esportes que 'curtem', produzem e reproduzem" (p. 72). Elas podem ser observadas na arte, na dança e na música. Na pesquisa de Tella, foram explorados mais especificamente as práticas do rap (música) e o break (dança).

O rap se apresenta como uma reação à essas tensões sociais e, de acordo com Tella, não só denuncia o racismo como também valoriza a imagem do negro e ainda constrói narrativas sobre cidades. Nesse sentido, o autor observa três aspectos principais presentes nas práticas juvenis: "o processo de identidade negra, a relação com seu bairro e a circulação pela cidade" (TELLA, 2020, p. 73). O aspecto visual das performances também é elencado pelo autor como uma importante forma comunicativa que gera identificação, distinção e reconhecimento entre 
os grupos. Repletas de sentidos e possibilidades de interpretação, Tella nos apresenta as práticas performáticas como pontos-chave para os estudos que buscam compreender os entrelaçamentos entre juventudes, raça e espaço urbano.

Os estudos antropológicos têm demonstrado que o hip-hop desempenha um importante papel na articulação política como movimento de expressão artística influente nos movimentos sociais e busca por reconhecimento, mas não somente. Partindo desse pressuposto, Вreitner Tavares nos apresenta outras esferas desta cultura: sua interface com o esporte através da mistura com torcidas organizadas de futebol, mas também como um meio para inserção produtiva e geração de renda para jovens.

A pesquisa foi realizada com jovens de diversos bairros da cidade de Maceió e com a participação em eventos locais de hip-hop, onde conheceram o grupo de rap Elementos Negros Conscientes (ENC). A partir da trajetória de um dos integrantes do grupo o autor vai mostrando como o engajamento no rap pode ampliar o repertório de possibilidades de vida e trabalho de jovens rappers. O estilo de vida empreendido pela cultura hip-hop e sua apresentação estética também alimentam e são alimentados por uma lógica de consumo de produtos, vestimentas, produção e participação em eventos. Diante disso, Tavares argumenta que o rap "produz não só valores, mas tabalho propriamente dito" (p. 208).

Embora ofereça oportunidades, Tavares mostra que a vida de rappers em Maceió também é atravessada por conflitos, e esses conflitos se tornam ainda mais acirrados quando entram em cena as rivalidades futebolísticas. Algumas das letras do grupo ENC fazem referência a um dos grandes times do Estado, que frequentemente se envolve em disputas violentas pelo time de futebol. As músicas as vezes geram tensões entre as torcidas, mas a inserção do rap nas torcidas organizadas, de acordo com os músicos entrevistados pelo pesquisador, tem o intuito de gerar uma mudança de consciência interna. O hip-hop, em sua pesquisa, além de ser uma manifestação cultural, também demonstra sua importância em outros aspectos das trajetórias juvenis, como no mundo do trabalho, mobilização política e na relação com torcidas organizadas.

Dando continuidade aos debates sobre expressões musicais, o texto de Frank Marcon nos leva a apreciar outros ritmos, desta vez de origens caribenhas e africanas. São as músicas que chegaram a Salvador e Lisboa, locus de pesquisa do autor, através das diásporas de países da África e do Caribe. Foi através da imigração que Kuduro, Afrobeat, Afrohouse, Azonto, Couple decale, Kwaito, Mahraganat e outros ritmos eletrônicos marcados pelo "beat do tambor" (p. 169), passaram a ser alguns dos estilos musicais tocados e dançados em festas dos circuitos de vida noturna em Salvador e Lisboa. 
As festas chamadas em Salvador de "festas africanas", além da diversão e do lazer, também proporcionam o reconhecimento e fortalecimento de vínculos entre jovens imigrantes, que através da dança e da música eles(as) "demarcam coletivamente sua presença na cidade" (p. 166). Maron e Tella, sobrecitado, concordam em suas observações que as performances são de grande importância para o reconhecimento interno e externo de grupos juvenis. Neste caso, os ritmos e as expressões corporais demarcam "modos de ser africanos" (p. 171), dando visibilidade às suas práticas e fortalecendo laços pessoais entre jovens imigrantes. Assim, sua pesquisa mostra que festas de música eletrônica africana não são somente atividades de lazer, como também possuem vocações políticas e estéticas importantes para a afirmação e reconhecimento de imigrantes africanos e caribenhos.

Na lógica capitalista as práticas de lazer frequentemente são mal vistas, interpretadas como "coisas de gente desocupada", principalmente quando se trata de moradores das favelas brasileiras, onde as taxas de desemprego são maiores do que no resto do país. Vanderlan Silva problematiza essas lógicas mercadológicas que fundamentam as concepções sobre lazer no conhecimento popular, a partir das repercussões de sua pesquisa na comunidade da Ramadinha, em Campina Grande.

Através da observação das interações entre moradores nas ruas e nas residências, Silva buscou compreender quais os sentidos de lazer рага moradores da comunidade da Ramadinha. Ele constata que os jogos de dominó, conversas em frente as casas, sinuca, festas e eventos na comunidade são muito mais do que somente práticas de lazer. Elas satisfazem a necessidade de "fuga das atividades mais regulares do cotidiano, especialmente daquelas que obrigam os indivíduos a permanecer por longas horas em ambiente de trabalho distante de suas moradias" (p. 146). Além disso, também podem ser consideradas formas de participação social, expressões de criatividade e organizadoras da vida na comunidade e fortalecedoras de redes entre moradores.

Silva nos mostra em seu artigo a complementaridade da relação entre o lazer e o trabalho, destacando a importância das formas de lazer em uma comunidade na Paraíba. É notável o fato de que as questões referentes ao trabalho em suas diferentes formas, seja ele trampo, bico ou corre atravessam diversas esferas da vida de jovens brasileiros, seja no lazer, nas práticas artísticas como o rap e o graffiti, ou nos desejos e projetos de vida. Além destes, Monica Franch e Josilene Pequeno apresentam outro domínio que também é regido por uma lógica do mundo do trabalho: o do tempo que organiza o cotidiano nas escolas.

Adotando uma perspectiva durkheimiana as autoras buscaram identificar as unidades elementares do tempo no calendário escolar. A partir de uma etnografia realizada em uma 
escola pública estadual em João Pessoa, as autoras argumentam que a organização temporal é algo que se aprende e se introjeta indiretamente através da aprendizagem escolar usual. Segundo as autoras, a forma de organização temporal da escola, рrepara, implicitamente, os jovens para o mundo do trabalho seguindo o princípio de "economia positiva do tempo" (p. 83). Ou seja, estudantes aprendem a fazer o maior aproveitamento possível do tempo, "extraindo dele o máximo de instantes disponíveis e de força útil" (FRANCH; PEQUENO, 2020, p. 83). A lógica de otimização do tempo conjugada com a ideia de que lazer é tempo gasto, como demonstra Vanderlan Silva, levam a concepções de vida em que o tempo de trabalho vale mais do que o tempo utilizado para outras práticas cotidianas, podendo gerar impactos negativos nas aspirações e projetos de jovens.

As ambições de vida e trabalho de jovens também são influenciadas por figuras de respeito nos grupos sociais a que pertencem. A partir de uma pesquisa desenvolvida com jovens e familiares que tem ou tiveram passagem pelo crime, residentes em uma grota ${ }^{5}$ em Maceió, Fernando Rodrigues reflete sobre a influência dos personagens policial e traficante, figuras de poder nesta localidade, nas escolhas de vida, nas concepções de justiça e nas formas de resolução de conflitos entre seus moradores. Estas figuras emblemáticas carregam em si uma série de significados que mobilizam as concepções de honra, respeito e justiça na grota e influenciam as relações familiares.

O caso de um pai que precisa fazer corres (roubo ou tráfico) para pagar as contas mas ao mesmo tempo precisa proteger seus filhos do mundo da criminalidade e também o caso do homem cuja passagem no mundo do crime fez com que desenvolvesse admiração pela polícia, ambos citados no artigo de Rodrigues, são ilustrativos das ambivalências entre as figuras do policial e do traficante. Nos bairros onde o cotidiano e as relações são regidas pela moralidade das facções e são frequentes as disputas com policiais, o repertório de exemplos de "ser bemsucedido" e de figuras de poder acaba sendo limitado a estes referenciais. Segundo o autor, "muitos dos repertórios simbólicos disponíveis mostram-se limitados, não indo além das ambições de trabalho e dinheiro" (FELTRAN, 2014 apud RODRIGUES, 2020). Estes são alguns dos fatores que influem nos repertórios de escolhas e valores nas vidas de jovens como os moradores desta grota, assim como as de muitos outros jovens brasileiros em contextos semelhantes.

A íntima relação entre juventudes e cidades é um assunto que perpassa todos os textos presentes nesta coletânea, aparecendo nas táticas inventivas de uso e apropriação dos espaços

\footnotetext{
${ }^{5}$ De acordo com Rodrigues (2020), “O termo é primo-irmão de 'favela', 'periferia' e 'gueto'” (p. 178).
} 
da cidade, nos modos de "se fazer ver" ou também como fatores socioespaciais condicionam experiências juvenis. Os mundos juvenis que se constroem nas tramas urbanas contemporâneas, podem ser pensados como "laboratórios que desafiam constantemente as ciências sociais", como sugere Ferreira (2017, p. 17). Das pesquisas realizdas nestes laboratórios surgem continuamente novas ideias para a compreensão antropológica das realidades juvenis.

O livro nos apresenta aspectos inovadores nos estudos sobre juventudes, entretanto, considerando as pautas atuais sobre gênero e sexualidade, cujas políticas e movimentos sociais têm sido protagonizados por jovens, poderiam ter sido incluídas nesta coletânea produções referentes a estas linhas temáticas. Trabalhos sobre normatividades e resistências, direito à cidade e suas apropriações, práticas performáticas, movimentos sociais, etc., renderiam contribuições importantes para enriquecer e diversificar ainda mais a coletânea.

Abordando questões sociais atuais nos debates públicos, o livro se faz necessário em um contexto em que as fissuras sociais se expandem, e as violências contra juventudes e suas formas de expressão se apresentam de formas cada vez mais brutais. Um exemplo dessa realidade é a tragédia no baile funk em Paraisópolis (SP) em dezembro de 2019, onde nove jovens foram mortos em uma ação policial. Diante de casos como este, produzir novos olhares рага as juventudes, evidenciando suas complexas realidades cotidianas e sua diversidade cultural, é um passo essencial para a construção de mundos mais receptivos às culturas juvenis e suas manifestações.

\section{REFERÊNCIAS}

CERTEAU, Michel. A invenção do cotidiano: 1. Artes de fazer. Petrópolis: Vozes, 2009.

FERREIRA, Vitor. Pesquisar Jovens. Caminhos e Desafios Metodológicos. Lisboa: ICS. Imprensa de Ciências Sociais, 2017.

MARCUS, George. Etnography In/Of the World System: the Emergence of Multi-Sited Ethnography. Annual Review of Anthropology, v. 24, p. 95-117, 1995.

Recebido em 27 de janeiro de 2021. Aprovado em 19 de outubro de 2021. 